\title{
Effect of Clodinafop-propargyl on Phalaris
}

\section{paradoxa L. (awned canary-grass) in wheat crop}

\section{Hajjaj B*, El Oualkadi A*}

\author{
${ }^{*}$ Regional Agricultural Research Center of Tangier, Morocco \\ Corresponding author. E-mail: h_badr15@yahoo.fr
}

\begin{abstract}
Phalaris paradoxa is problematic weed that decrease considerably wheat crop yields. The aim of this study is to investigate the effect of Clodinafop-propargyl on Phalaris paradoxa infestation in a soft wheat crop. The experimental design was Randomized Complete Block Design (RCBD) with three replications. Each block contained 4 elementary plots, 3 plots of which were treated with three rates of application of Clodinafoppropargyl and one untreated control plot. Observations concerned Percentage of Phalaris paradoxa density reduction and biomass reduction. Results showed that treatments with Clodinafop-propargyl at $60 \mathrm{~g} / \mathrm{ha}$ and 80 g/ha gave the best control of Phalaris paradoxa infestations recording respectively $96.2 \%$ and $98.5 \%$ of Phalaris paradoxa density reduction and $95.5 \%$ and $99.3 \%$ of Phalaris paradoxa dry biomass reduction. Clodinafop-propargyl at $40 \mathrm{~g} / \mathrm{ha}$ recorded lower efficacies $77.1 \%$ and $82.3 \%$ respectively on Phalaris paradoxa density reduction, and Phalaris paradoxa dry biomass reduction.
\end{abstract}

Keywords-Phalaris paradoxa, Clodinafop-propargyl, wheat, density, biomass.

\section{INTRODUCTION}

Weeds are a major problem on wheat production in Morocco as they compete on water, minerals and sunlight and make harvest operation more difficult (Zimadahl \& El Brahli, 1992; Boutahar, 1994; Taleb, 1996; Bouhache, 2007; Bouhache, 2017). Phalaris paradoxa L. (awned canary-grass) belongs to Poaceae botanical Family. It is an annual plant. Upright $20 \mathrm{~cm}$ to $1.20 \mathrm{~m}$ high (Tanji, 2005). Leaves 10 to $20 \mathrm{~cm}$ long and 5 to $10 \mathrm{~mm}$ wide. Membrane ligules, 3 to $4 \mathrm{~mm}$ long. No auricles. Inflorescence is a compact and rough panicle, sometimes wrapped by the upper leaf, cylindrical, narrowed at the base, 3 to $10 \mathrm{~cm}$ long and 1 to $2 \mathrm{~cm}$ wide. Palms of the panicle made up of beams of 5 to 7 spikelets (Tanji, 2005). Central spikelets are fertiles, the others steriles. Oval seeds, hairless, shiny, 3 to $4 \mathrm{~mm}$ long and 1 to $2 \mathrm{~mm}$ wide without chip at the base, usually having 3 long lines on each side. Seedling is hairless, coiled prefoliation. First leaves 5 to $10 \mathrm{~cm}$ long and 1 to $2 \mathrm{~mm}$ wide. Membrane ligule, 1 to $4 \mathrm{~mm}$. Seed determination makes it easier to recognize the seedling (Tanji, 2005). Plant lying on different types of soil and consumed by animals. Seeds are usually consumed by birds. Clodinafop-propargyl is an herbicide that belongs to Aryloxyphenoxy-propionate 'FOPs' family. It is a systemic herbicide absorbed by leaves to control grasses. It causes inhibition of acetyl CoA carboxylase (ACCase) which is an enzyme that catalyzes the fatty-acid synthesis (Ezzahiri \& al., 2017). Clodinafop-propargyl inhibits the ACCase enzyme activity, thus blocking the production of phospholipids necessary for synthesizing the lipid bilayer, which is indispensable for cell structure and function. Phalaris paradoxa decrease considerably cereal yields in Ouazzan region of Morocco. The aim of this study is to compare the effect of three doses of Clodinafop-propargyl on Phalaris paradoxa infestation in a soft wheat crop in the Ouazzan region of Morocco.

\section{MATERIAL AND METHODS}

A weed control trial was conducted in Ouazzane region of Morocco during 2017-2018 growing season. The experimental design was Randomized Complete Block Design (RCBD) with three replications. The distance between the blocks was 2 meters and the distance between plots was 1 meter. Each block contained 4 elementary plots, 3 plots of which were treated with the postemergence herbicides tested (Table 1) and one untreated control plot. The size of the elementary plots was $2 \mathrm{~m}$ x $5 \mathrm{~m}$ $\left(10 \mathrm{~m}^{2}\right)$. Treatments was carried out on January 2, 2018 with a Knapsack herbicide sprayer with nozzle delivering a 3 bar jet. The spray volume per hectare is 200L. Treatments consist on three rates of application of Clodinafop-propargyl (Table 1). Observations were at 60 days after application of herbicides. Observations concerned Percentage of Phalaris paradoxa density reduction and biomass reduction. Phalaris paradoxa density reduction percentage $=[$ Phalaris paradoxa density in control plots - Phalaris paradoxa density in treated plots] x 100 / [Phalaris paradoxa density in control plots], 
Calculation of the density at the experimental level of the plot was made by a quadrant of $1 \mathrm{~m} \times 1 \mathrm{~m}$. Phalaris paradoxa dry biomass reduction percentage $=[$ Phalaris paradoxa dry biomass weight in control plots - Phalaris paradoxa dry biomass weight in treated plots] $\mathrm{x} 100 /$ [Phalaris paradoxa dry biomass weight in control plots]. Calculation of dry Phalaris paradoxa biomass were made by collecting Phalaris paradoxa in each plot using a quadrant of $1 \mathrm{~m} \times 1 \mathrm{~m}$. Samples were dried in a drying oven at $75^{\circ} \mathrm{C}$ for 48 hours. Then, dry plant material in each plot were weighed with a precision balance. Statistical analyzes were performed with IBM SPSS Statistics, version 21.0 using the analysis of variance (ANOVA).The differences among treatment means was compared by Tukey's test at $P=0.05$.

Table 1: Applied herbicides in experimental site

\begin{tabular}{llc}
\hline $\begin{array}{l}\text { Herbicide } \\
\text { treatments }\end{array}$ & $\begin{array}{l}\text { Herbicide active } \\
\text { ingredient }\end{array}$ & $\begin{array}{l}\text { rate } \\
\text { application } \\
\text { (g/hectare) }\end{array}$ \\
\hline Treatment 1 & $\begin{array}{l}\text { Clodinafop- } \\
\text { propargyl }\end{array}$ & $40 \mathrm{~g} / \mathrm{ha}$ \\
\hline Treatment 2 & $\begin{array}{l}\text { Clodinafop- } \\
\text { propargyl }\end{array}$ & $60 \mathrm{~g} / \mathrm{ha}$ \\
\hline Treatment 3 & $\begin{array}{l}\text { Clodinafop- } \\
\text { propargyl }\end{array}$ & $80 \mathrm{~g} / \mathrm{ha}$ \\
\hline
\end{tabular}

\section{RESULTS AND DISCUSSION}

\section{Effect on Phalaris paradoxa density reduction}

Statistical analysis revealed significant differences between treatments (Table 2). Results in Table 2 showed that the best Phalaris paradoxa density reduction was obtained by Clodinafop-propargyl at $60 \mathrm{~g} / \mathrm{ha}$ and $80 \mathrm{~g} / \mathrm{ha}$ recording respectively $96.2 \%$ and $98.5 \%$ of Phalaris paradoxa density reduction. Clodinafop-propargyl at 40 $\mathrm{g} /$ ha showed lower efficacy recoding $77.1 \%$ of Phalaris paradoxa density reduction (fig. 1).

Table 2: Effect of treatments on Phalaris paradoxa density reduction (\%)

\begin{tabular}{lc} 
Doses & $\begin{array}{c}\text { Phalaris paradoxa } \\
\text { density reduction }\end{array}$ \\
\hline $\begin{array}{l}\text { Clodinafop-propargyl at } 40 \\
\text { g/ha }\end{array}$ & $77.1^{\mathrm{a}}$ \\
\hline $\begin{array}{l}\text { Clodinafop-propargyl at } 60 \\
\text { g/ha }\end{array}$ & $96.2^{\mathrm{b}}$ \\
$\begin{array}{l}\text { Clodinafop-propargyl at } 80 \\
\text { g/ha } \quad P \alpha=0.05\end{array}$ & $98.5^{\mathrm{b}}$ \\
\hline
\end{tabular}

Significant differences within the same column and means followed by the same letter do not differ at $P=0.05$ according to Tukey's test

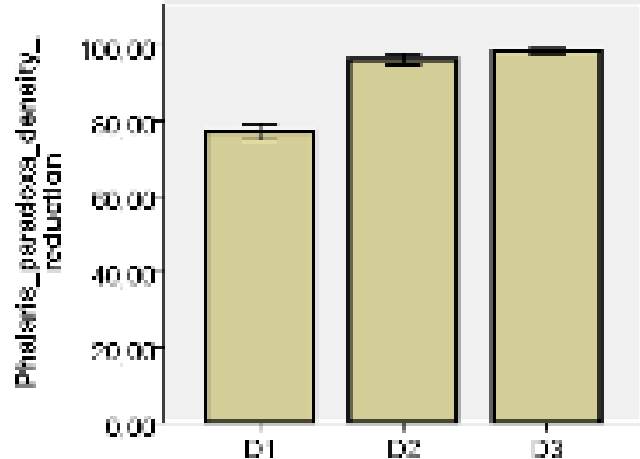

D1: Clodinafop-propargyl at $40 \mathrm{~g} / \mathrm{ha}$; D2: Clodinafop-propargyl at $60 \mathrm{~g} / \mathrm{ha}$; D3: Clodinafop-propargyl at $80 \mathrm{~g} / \mathrm{ha}$

Error Bars: 95\% CI

Fig.1: Effect of treatments on Phalaris paradoxa density reduction (\%)

Effect on Phalaris paradoxa dry biomass reduction Statistical analysis revealed significant differences between treatments (Table 3). Data in Table 3 indicate that the best Phalaris paradoxa dry biomass reduction was achieved by Clodinafop-propargyl at $60 \mathrm{~g} / \mathrm{ha}$ and $80 \mathrm{~g} / \mathrm{ha}$ recording respectively $95.5 \%$ and $99.3 \%$ of Phalaris paradoxa dry biomass reduction. Concerning the effect of Clodinafop-propargyl at $40 \mathrm{~g} / \mathrm{ha}$, results showed lower efficacy recording $82.3 \%$ of Phalaris paradoxa dry biomass reduction (fig. 2).

Table 3: Effect of treatments on Phalaris paradoxa dry biomass reduction (\%)

Doses Phalaris paradoxa density reduction

\begin{tabular}{cc}
\hline Clodinafop-propargyl at $40 \mathrm{~g} / \mathrm{ha}$ & $82.3^{\mathrm{a}}$ \\
\hline Clodinafop-propargyl at $60 \mathrm{~g} / \mathrm{ha}$ & $95.5^{\mathrm{b}}$ \\
\hline Clodinafop-propargyl at $80 \mathrm{~g} / \mathrm{ha}$ & $99.3^{\mathrm{b}}$ \\
\hline$P \alpha=0.05$ & $<0.001$ \\
\hline
\end{tabular}

Significant differences within the same column and means followed by the same letter do not differ at $P=0.05$ according to Tukey's test

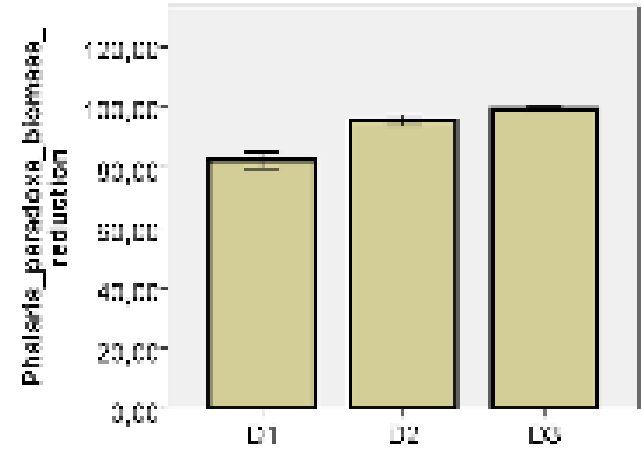

D1: Clodinafop-propargyl at $40 \mathrm{~g} / \mathrm{ha}$; D2: Clodinafoppropargyl at $60 \mathrm{~g} / \mathrm{ha}$; D3: Clodinafop-propargyl at $80 \mathrm{~g} / \mathrm{ha}$ Error Bars: 95\% CI

Fig.2: Effect of treatments on Phalaris paradoxa dry biomass reduction (\%) 


\section{CONCLUSION}

This study has shown that the herbicide Clodinafoppropargyl at $60 \mathrm{~g} / \mathrm{ha}$ and $80 \mathrm{~g} / \mathrm{ha}$ gave the best control of Phalaris paradoxa. Clodinafop-propargyl at $40 \mathrm{~g} / \mathrm{ha}$ lower control of Phalaris paradoxa. Thus, Clodinafop-propargyl at $60 \mathrm{~g} / \mathrm{ha}$ can be recommended to farmers in Ouazzane region when Phalaris paradoxa infestation is dominant.

\section{ACKNOWLEDGMENTS}

The authors are grateful to all technicians of ONCA Ouazzan for providing necessary facilities for conducting this research work.

\section{REFERENCES}

[1] Bouhache M. (2017). Chemical weed control in autumn sown cereals. Agriculture du Maghreb Num. 25: 57-62. French.

[2] Bouhache M. (2017). Strengths and weaknesses of herbicides used on cereals in Morocco. Agriculture du Maghreb Num. 100: 9-19. French

[3] Boutahar K. (1994). Impact of harvest date and presence of weeds on grain losses at harvest operation. Al Awamia Num. 85: 25-32. French.

[4] Ezzahiri B., Bouhache M., Mihi M. (2017). Phytosanitary index of Morocco. AMPP Maroc Editions. French.

[5] IBM SPSS Statistics for Windows, Version 21.0. (2012). Armonk, NY: IBM Corp.

[6] Taleb A. (1996). Weed flora of Morocco, Characterization and economic importance. Bulletin de transfert de technologie en agriculture Rabat Maroc, Num. 18. French.

[7] Tanji A. (2005). Weeds of wheat and barley in Morocco. INRA Editions, Rabat Morocco. French

[8] Zimadahl RL , El Brahli A. (1992). Losses caused by weeds on cereals in the semi-arid zone of western Morocco. Al Awamia Num. 75: 53-62. French 